Article

\title{
Applications of Microencapsulated Bifidobacterium Longum with Eleutherine Americana in Fresh Milk Tofu and Pineapple Juice
}

\section{Atchara N. Phoem ${ }^{1}$, Suphitchaya Chanthachum ${ }^{2}$ and Supayang P. Voravuthikunchai ${ }^{3, *}$}

1 Department of Biology and Applied Biology, Faculty of Science and Technology, Songkhla Rajabhat University, Muang, Songkhla 90000, Thailand; E-Mail: aphoem@yahoo.com Department of Food Technology, Faculty of Agro-industry, Prince of Songkla University, Hat Yai, Songkhla 90112, Thailand; E-Mail: suphitchaya.c@psu.ac.th

3 Department of Microbiology and Excellent Research Laboratory on Natural Products, Faculty of Science and Natural Product Research Center of Excellence, Prince of Songkla University, Hat Yai, Songkhla 90112, Thailand

* Author to whom correspondence should be addressed; E-Mail: supayang.v@psu.ac.th; Tel./Fax: +66-7444-6661.

Received: 6 December 2014 / Accepted: 20 March 2015 / Published: 3 April 2015

\begin{abstract}
Bifidobacterium longum was microencapsulated by extrusion technique and added in fresh milk tofu and pineapple juice. Microencapsulation of B. longum with Eleutherine americana extract, oligosaccharides extract, and commercial fructo-oligosaccharides was assessed for the bacterial survival after sequential exposure to simulated gastric and intestinal juices, and refrigeration storage. Microencapsulated $B$. longum with the extract and oligosaccharides extract in the food products showed better survival than free cells under adverse conditions. Sensory analysis demonstrated that the products containing co-encapsulated bacterial cells were more acceptable by consumers than free cells. Pineapple juice prepared with co-encapsulated cells had lower values for over acidification, compared with the juice with free cells added. This work suggested that microencapsulated B. longum with E. americana could enhance functional properties of fresh milk tofu and pineapple juice.
\end{abstract}

Keywords: Bifidobacterium longum; Eleutherine americana; fresh milk tofu; microencapsulation; pineapple juice 


\section{Introduction}

Functional foods provide a health benefit that goes beyond general nutritional content, and particularly foods containing probiotics are a natural way of enhancing the functionality of food products [1]. Viability of probiotics must be maintained throughout the product's shelf-life and gastrointestinal conditions. Maintenance of their survival until they reach the gastrointestinal tract is one of the key requirements for health benefit. International Dairy Federation (IDF) has suggested that a minimum of $10^{7} \mathrm{CFU}$ probiotic bacterial cells should be alive at the time of consumption per gram of the product. Bifidobacteria, a group of commonly selected probiotics, are dominant in infant gut microbiota [2].

The most common probiotic-containing foods are dairy products. The dairy products have a place in delivering probiotics to human gut, as they provide a suitable environment for their viability [2]. However, probiotics may show low survival in fermented milk products due to their acidic nature. Probiotics may be incorporated into fresh milk tofu which is a suitable environment for probiotic delivery in human foods. The fresh milk tofu shows $\mathrm{pH}$ of 6.2 and contains more solid content, which creates the possibility for satisfactory viability of probiotics. Lactose intolerance, cholesterol content, and allergic milk proteins are not suitable for intake of dairy products and give rise to the development of non-dairy products as an ideal delivery media for probiotics [3]. Fruit juices, particularly pineapple juice, could be a healthy probiotic carrier food due to its high nutritional value including vitamins and antioxidants [4]. Moreover, there is no starter culture in the juice like yoghurt which can compete with probiotics, and loss in viability occurs during refrigeration storage [5].

Microencapsulation by extrusion technique has been applied for the protection of the probiotics against gastrointestinal transit and food products. A combination of alginate with prebiotic oligosaccharides produces beads with a good integrate structure resulted in the improvement of probiotic viability in adverse environmental conditions [6]. It has previously been reported that microencapsulation of probiotics with resistant starch [7] and chitosan [8] was able to increase the survival of probiotics in dairy and non-dairy products during refrigeration storage and gastrointestinal conditions.

Prebiotics oligosaccharides appear naturally in fruits, vegetables, milk, and honey. Eleutherine americana Merr. is a herbal plant whose red bulb has been used in Asian cuisine. There have been a number of studies on E. americana extract for applications in clinical [9] and food preservation [10]. Furthermore, hot water extract from E. americana has been used to provide growth stimulation on beneficial bacteria [11]. However, survival of microencapsulated probiotic with E. americana oligosaccharides in fresh milk tofu and pineapple juice has not yet been documented. Furthermore, no reports were found in the literature about the sensory evaluation of each product.

Therefore, the objectives of this study were to evaluate the enhanced survival of microencapsulated Bifidobacterium longum with Eleutherine americana extract and oligosaccharides extract in food products under gastrointestinal conditions and refrigeration storage. Sensory scores of the food products were assessed. 


\section{Materials and Methods}

\subsection{Probiotic Bacteria from Infant Faeces}

Faeces from healthy infants were collected and bifidobacteria were isolated from collected samples by the method of Phoem and Voravuthikunchai [12]. Twenty-three isolates were investigated for characterization as potential probiotics. Bifidobacterium longum (isolate 4) showed good probiotic properties including high acid tolerance at $\mathrm{pH}$ of 2 and bile resistance at $0.30 \%$ oxgall, high protein, lipid, starch, Eleutherine americana extract utilizations, good antibacterial activity against Staphylococcus aureus ATCC 27664 and Salmonella Typhimurium ATCC 13311. B. longum was used as the target strain in this present work.

B. longum cells were cultivated in $50 \mathrm{~mL}$ of MRS broth (Merck, Damstadt, Germany) supplemented with $0.05 \%(\mathrm{w} / \mathrm{v}) \mathrm{L}$-cysteine hydrochloride and incubated at $37^{\circ} \mathrm{C}$ under anaerobic condition for $24 \mathrm{~h}$. They were centrifuged at $10,000 \mathrm{~g}$ for $10 \mathrm{~min}$, at $4{ }^{\circ} \mathrm{C}$. The pellets were washed with $0.1 \%(\mathrm{w} / \mathrm{v})$ pre-reduced normal saline solution and re-suspended in $10 \mathrm{~mL}$ of $0.1 \%(\mathrm{w} / \mathrm{v})$ pre-reduced peptone solution. The cell suspensions were adjusted to final concentration of approximately $1 \times 10^{10} \mathrm{CFU} \mathrm{mL} \mathrm{m}^{-1}$. They were divided into two groups: one part was used for microencapsulation and the other as free cells.

\subsection{Eleutherine Americana Extract and Oligosaccharides Extract}

Bulbs of E. americana were collected from Songkhla, Thailand. They were extracted by hot water according to the method of Phoem and Voravuthikunchai [11]. Briefly, the bulbs were extracted with distilled water in ratio of $1: 10(\mathrm{w} / \mathrm{v})$ at $80{ }^{\circ} \mathrm{C}$ for $1 \mathrm{~h}$. The filtrates were dried by freeze dryer (Flexi Dry, Germany).

E. americana extract was partially-purified using Saccharomyces cerevisiae BCC 12652 and then precipitated twice by $80 \%$ ethanol at $4{ }^{\circ} \mathrm{C}$ for $12 \mathrm{~h}$ [11]. The oligosaccharides extract was analyzed for fructo-oligosaccharides by High Performance Liquid Chromatography (HPLC 1100, Hewlette Packard, Germany). Commercial fructo-oligosaccharides (Sigma-Aldrich, Steinheim, Germany) was used as reference. The extract, oligosaccharides extract, and commercial fructo-oligosaccharides were dissolved in sterile distilled water and used for further studies.

\subsection{Microencapsulation of Bifidobacterium Longum with Eleutherine Americana}

The extrusion technique was performed for microencapsulation process as described previously [13]. Briefly, two milliliters of cell suspension $\left(1 \times 10^{10} \mathrm{CFU} \mathrm{mL} \mathrm{mL}^{-1}\right)$ were mixed with $16 \mathrm{~mL}$ of sterile 2\% (w/v) sodium alginate solution (Fluka, Switzerland). Two milliliters of E. americana extract, oligosaccharides extract, and commercial fructo-oligosaccharides were separately added to the above mixtures to make final concentration of $1 \%(w / v)$. Final concentration of cell suspension in the mixture

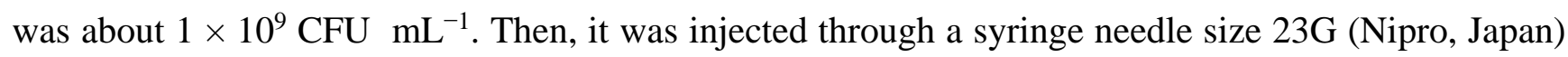
into sterilized $0.1 \mathrm{M} \mathrm{CaCl}_{2}$ solution (Difco, Dickinson, TX, USA) from the distance of $10 \mathrm{~cm}$ that formed beads. Beads were allowed to harden for $30 \mathrm{~min}$ in $\mathrm{CaCl}_{2}$ solution. They were washed twice with $0.85 \%(\mathrm{w} / \mathrm{v})$ pre-reduced normal saline solution and stored in $0.1 \%(\mathrm{w} / \mathrm{v})$ pre-reduced peptone solution (pH 6) at $4{ }^{\circ} \mathrm{C}$ until use. The free cells were used as control. 


\subsection{Application of Microencapsulated Bifidobacterium Longum in Fresh Milk Tofu (Dairy Product)}

\subsubsection{Preparation of Fresh Milk Tofu}

The ingredients for fresh milk tofu were $7 \mathrm{~g}$ of agar (Pearl Mermaid, Bangkok, Thailand), $50 \mathrm{~g}$ of sugar, $700 \mathrm{~mL}$ of Ultra-High-Temperature plain milk (UHT, Nongpho, Ratchaburi, Thailand), and $300 \mathrm{~mL}$ of water. Agar was dissolved in water and stirred until boil. Sugar and UHT plain milk were added with high-speed stirring. Heating was continued to $65{ }^{\circ} \mathrm{C}$ and the mixture was kept at this temperature for 15-20 min. The mixture was divided into four equal fractions and cooled to $45{ }^{\circ} \mathrm{C}$. Microencapsulated B. longum with E. americana extract, oligosaccharides extract, commercial fructo-oligosaccharides, and free cells were added aseptically into the mixture. Beads and free cells were added at concentrations about $1 \times 10^{9} \mathrm{CFU} \mathrm{g} \mathrm{g}^{-1}$ and $1 \times 10^{9} \mathrm{CFU} \mathrm{\textrm {mL } ^ { - 1 }}$, respectively. The ratio of beads and free cells to fresh milk tofu was 1:10. The fresh milk tofu $(\mathrm{pH}$ 6.2) was distributed in sterile plastic cups, topped with UHT plain milk plus sugar, and packed with sterile plastic lids. All experiments were performed in duplicate.

\subsubsection{Survival of Microencapsulated Bifidobacterium Longum after Sequential Incubation in} Simulated Human Gastric and Intestinal Juices

Microencapsulated B. longum and free cells were stored in fresh milk tofu at $4{ }^{\circ} \mathrm{C}$ for $0,2,4$, and 6 days and determined for their survival after exposure to simulated gastric and intestinal juices. Briefly, simulated gastric juice was mimicked by hydrochloric acid $(\mathrm{HCl})$ buffer of $\mathrm{pH} 2$ containing: $\mathrm{NaCl}-8 \mathrm{~g} \mathrm{~L}^{-1}$; KCl-0.2 g L L ${ }^{-1} ; \quad \mathrm{Na}_{2} \mathrm{HPO}_{4} \cdot 2 \mathrm{H}_{2} \mathrm{O}-8.25$ g L L ${ }^{-1}$; $\mathrm{NaH}_{2} \mathrm{PO}_{4}-14.35$ g L L $\mathrm{L}^{-1} \mathrm{CaCl}_{2} \cdot 2 \mathrm{H}_{2} \mathrm{O}-0.1$ g L L $\mathrm{MgCl}_{2} \cdot 6 \mathrm{H}_{2} \mathrm{O}-0.18 \mathrm{~g} \mathrm{~L}^{-1}$ and pepsin (Sigma-Aldrich)-3 $\mathrm{g} \mathrm{L}^{-1}$ as described by Sandoval-Castilla et al. [14]. The fresh milk tofu containing microencapsulated B. longum $(10 \mathrm{~g})$ and free cells $(10 \mathrm{~mL})$ were added to $90 \mathrm{~mL}$ of simulated gastric juice and incubated at $37^{\circ} \mathrm{C}$ under anaerobic condition for $3 \mathrm{~h}$ in a rotary shaker. One gram of fresh milk tofu containing microencapsulated B. longum and free cells (1 mL) was added to $9 \mathrm{~mL}$ of $0.1 \mathrm{M}$ pre-reduced phosphate buffer ( $\mathrm{pH}$ 7.4) followed by homogenization in stomacher for $5 \mathrm{~min}$. The samples were then centrifuged at $10,000 \mathrm{~g}$ for $10 \mathrm{~min}$, at $4{ }^{\circ} \mathrm{C}$. The pellet was serially diluted with normal saline solution and plated on MRS agar modified with the addition of $0.05 \%$ (w/v) L-cysteine hydrochloride. The plates were incubated at $37^{\circ} \mathrm{C}$ under anaerobic condition for $48 \mathrm{~h}$. After incubation, viable cells were counted and expressed as log colony-forming units per gram $\left(\log _{10} \mathrm{CFU} \mathrm{g} \mathrm{g}^{-1}\right)$. The samples after having been exposed to simulated gastric juice were centrifuged, washed with $0.85 \%$ (w/v) pre-reduced normal saline solution, and deposited in $9 \mathrm{~mL}$ of simulated intestinal juice (pH 7.4) containing: $\mathrm{NaCl}-6.50 \mathrm{~g} \mathrm{~L}^{-1}$; KCl-0.84 $\mathrm{g} \mathrm{L}^{-1}$; $\mathrm{CaCl}_{2}-0.22 \mathrm{~g} \mathrm{~L}^{-1}$; $\mathrm{NaHCO}_{3}-1.39 \mathrm{~g} \mathrm{~L}^{-1}$; $L$-cysteine hydrochloride- $0.50 \mathrm{~g} \mathrm{~L}^{-1}$; bile salt (Difco)-3 $\mathrm{g} \mathrm{L}^{-1}$; and pancreatin-1 $\mathrm{g} \mathrm{L}^{-1}$ (Sigma-Aldrich). They were anaerobically incubated at $37^{\circ} \mathrm{C}$ for $3 \mathrm{~h}$ in a rotary shaker. The samples were centrifuged, washed with normal saline solution, and counted of viable cells as described in Section 2.4.2. All experiments were performed in duplicate.

\subsubsection{Survival of Microencapsulated Bifidobacterium Longum under Refrigeration Storage}

The effect of refrigeration storage at $4{ }^{\circ} \mathrm{C}$ for $0,2,4$, and 6 days in the survival of microencapsulated B. longum and free cells was assessed by following a modified method of Brinques and Ayub [15]. They 
were used for viable cell count after depolymerization of their cells in stomacher as described in Section 2.4.2. All experiments were performed in duplicate.

\subsubsection{Sensory Evaluation}

Sensory evaluation of stored fresh milk tofu was carried out according to the method proposed by Bergara-Almeida et al. [16]. The study has been approved by the Ethics Committee of Prince of Songkla University, Thailand. A total of 20 trained panelists evaluated the samples for attributes of appearance, colour, texture, taste, and overall acceptability at $4{ }^{\circ} \mathrm{C}$ for $0,2,4$, and 6 days. All experiments were performed in duplicate. Sensory evaluation was based on a nine-point hedonic scale, where 9 = extremely desirable, 5 = moderately desirable, and $1=$ extremely undesirable. Five samples of each food product containing co-encapsulated B. longum with E. americana extract, oligosaccharides extract, and commercial fructo-oligosaccharides, non-encapsulated $B$. longum, and control (without B. longum and co-encapsulating agents), were presented to the panelists in individual plastic coded containers. The samples were randomly presented to the panel group at each session. Water was used for mouth rinsing between samples.

\subsection{Application of Microencapsulated Bifidobacterium Longum in Pineapple Juice (Non-Dairy Product)}

\subsubsection{Preparation of Pineapple Juice}

Fresh raw pineapples (Ananas comosus (Linn.) Merr.) were obtained from a local market and washed in water. The fruit was peeled, cut, and ground with high speed for 1 min (Tefal Kaleo, France). The sample was passed through a mesh screen to remove pieces of flesh. One liter of the sample was sterilized and cooled to $25{ }^{\circ} \mathrm{C}$. Microencapsulated B. longum with E. americana extract, oligosaccharides extract, commercial fructo-oligosaccharides, and free cells were separately added aseptically into pineapple juice. Beads and free cells were added at concentrations about $1 \times 10^{9} \mathrm{CFU} \mathrm{g}^{-1}$ and $1 \times 10^{9} \mathrm{CFU} \mathrm{mL}^{-1}$, respectively. The ratio of beads and free cells to the juice was 1:10. The pineapple juice ( $\mathrm{pH} 3.8)$ was allocated to sterile bottles, and packed with sterile plastic lids. All experiments were done in duplicate.

\subsubsection{Survival of Microencapsulated Bifidobacterium Longum after Sequential Incubation in} Simulated Human Gastric and Intestinal Juices

Microencapsulated B. longum and free cells were kept in pineapple juice at $4{ }^{\circ} \mathrm{C}$ for 0,15 , 30, and 45 days and their survival was determined as the similar method described in Section 2.4.2.

\subsubsection{Survival of Microencapsulated Bifidobacterium Longum under Refrigeration Storage}

Pineapple juice containing microencapsulated $B$. longum and free cells were performed in the similar method as described in Section 2.4.3 and their survival was determined by the day of 0, 15, 30, and 45 .

\subsubsection{Sensory Evaluation}

Sensory evaluation of refrigerated pineapple juice during 45 days was treated in a similar way as described in Section 2.4.4. 


\subsubsection{Production of Organic Acids in Pineapple Juice}

Production of acetic and lactic acids in pineapple juice stored at $4{ }^{\circ} \mathrm{C}$ for $0,15,30$, and 45 days was determined by modified the method of Holdeman et al. [17]. The samples were centrifuges at $10,000 \mathrm{~g}$ for $15 \mathrm{~min}$, at $4{ }^{\circ} \mathrm{C}$ and supernatant were estimated by gas chromatography equipped with a flame ionization detection and HP-INNOWAX capillary column. The concentration of the acids was quantified by comparing with peak area of respective standard. The $\mathrm{pH}$ of the samples was determined with a $\mathrm{pH}$ meter (Beckman Instruments, Fullerton, CA, USA). All experiments were done in duplicate.

\subsection{Statistical Analysis}

The data were reported as mean \pm standard deviation (S.D.). Differences among groups were examined for statistical significance by analysis of variance (ANOVA). The criterion for significance was $p<0.05$.

\section{Results and Discussion}

\subsection{Viability of Microencapsulated Bifidobacterium Longum in Fresh Milk Tofu}

The diameter of beads made by the extrusion technique was $1.65-2.05 \mathrm{~mm}$ and their shapes were round. The type of co-encapsulating agents had no influence on the size of the beads. Survival of microencapsulated $B$. longum with extracts and free cells in fresh milk tofu after sequential incubation in simulated gastric and intestinal juices is shown in Table 1 . The initial number of $B$. longum cells were in the range of $9.30-9.46 \log _{10} \mathrm{CFU} \mathrm{g}^{-1}$ beads. The beads made by extrusion technique were kept at $4{ }^{\circ} \mathrm{C}$ for $0,2,4$, and 6 days. The number of $B$. longum cells reduced after refrigeration storage. Survival rates of co-encapsulated cells before and after exposure to acidic and enzymatic conditions were better than those of non-encapsulated cells $(p<0.05)$. The alginate used comprised high mannuronic acid (M) and guluronic acid $(\mathrm{G})$. M:G ratio can be manipulated to increase the permeability of gels to enhance the survival of co-encapsulated cells [8]. In addition, microencapsulated B. longum with E. americana might be acting as buffer against acids. The presence of food may affect survival as the probiotics may not be exposed to acid and enzyme [18]. The number of microencapsulated cells decreased when exposed to the simulated juices at day 4 and 6 . The highest survival of viable cells resulted from microencapsulation with the oligosaccharides extract at day 6 . Higher enzymatic resistance of the oligosaccharides extract might be due to presence of $\beta$ and $\alpha$-glycosidic linkage in the oligosaccharides extract. The viability of $B$. longum microencapsulation with the oligosaccharides extract decreased from 9.24-8.23 $\log _{10} \mathrm{CFU} \mathrm{g}^{-1}$ after exposure to the simulated juices.

Effect of refrigeration storage on viability of microencapsulated B. longum with extracts and free cells is shown in Table 1. Initial cell concentration of B. longum was in the range of 9.44-9.54 $\log _{10}$ CFU $\mathrm{g}^{-1}$ beads. The cell numbers of $\mathrm{B}$. longum reduced after refrigeration storage. The viability of co-encapsulated cells was higher than that of non-encapsulated cells at day 2,4 , and $6(p<0.05)$. There was a reduction of pore size, thus hindering the interaction between cells and the composition of food product during storage [18]. The highest numbers of B. longum were observed when microencapsulated with oligosaccharides extract on day 6 . The survival of microencapsulated $B$. longum with the oligosaccharides extract was $9.24 \log _{10} \mathrm{CFU} \mathrm{g}{ }^{-1}$. Accordingly, microencapsulated probiotics with 
prebiotics improved the viability than that of free cells in cheese [7,19], ice cream [20], and frozen yoghurt [21] during refrigeration storage.

\subsection{Sensory Analysis of Fresh Milk Tofu}

Sensory scores of fresh milk tofu containing microencapsulated B. longum with co-encapsulating agents, free cells, and control at $0,2,4$, and 6 days of refrigeration storage are presented in Table 2. Initially, there was no significant difference in appearance, colour, texture, taste, and overall acceptability in all samples $(p>0.05)$. Higher score of fresh milk tofu containing microencapsulated $B$. longum was maintained during refrigeration storage whereas the scores of free cells and control decreased after storage period. Overall acceptability of fresh milk tofu samples containing co-encapsulated cells was higher than the samples with free cells at day 4 and $6(p<0.05)$. The type of co-encapsulating agents had no influence on sensory scores of all samples. The mean scores for fresh milk tofu containing microencapsulated $B$. longum ranged between 7.26 and 7.56 (where 7 = like moderately) for overall acceptability. The use of prebiotics as a co-encapsulating agent could have influenced smoothness of the food samples. Casein rearrangement around the microcapsules could result in continuous structure. In addition, co-encapsulating agents used in extrusion technique may have influenced the grittiness of the samples [22]. On the other hand, this could have been the reason that microencapsulated B. longum with E. americana appeared white and did not have an impact on color. Accordingly, sensory scores of white brined cheese containing microencapsulated probiotic with resistant starch were higher than that of free cells during refrigeration storage [7].

\subsection{Viability of Microencapsulated Bifidobacterium Longum in Pineapple Juice}

Effects of simulated gastric and intestinal juices and refrigeration storage on survival of microencapsulated B. longum with extracts and free cells is shown in Table 3. The beads were kept in pineapple juice at $4{ }^{\circ} \mathrm{C}$ for $0,15,30$, and 45 days. The number of viable cells decreased after exposure to the simulated juices and refrigeration storage. The survival of co-encapsulated cells after exposure to the adverse conditions was better than that of non-encapsulated cells at day 15, 30, and 45 $(p<0.05)$. The highest number of $B$. longum resulted from microencapsulation with the oligosaccharides extract. The survival of $B$. longum microencapsulation with the oligosaccharides extract was reduced from 8.23 to $7.25 \log _{10} \mathrm{CFU} \mathrm{g}^{-1}$ in the presence of the simulated juices, and that of refrigeration storage was $8.28 \log _{10} \mathrm{CFU} \mathrm{g}{ }^{-1}$ at day 45 . Mokarram et al. [18] have observed that the microencapsulated probiotics with two layers of alginate resulted in a reduction of pore size which provided more favorable anaerobic environment for the bacterial cells. In a similar way from the attained result of the present study, it is envisaged that E. americana may have similar effects on B. longum cells. However, no survival of non-encapsulated cells was noted at day 30 and 45. Shabala et al. [23] suggested that acids reduce viability of bacteria by acidifying cytoplasm and inhibition of enzymatic reactions. Probiotic viability in fruit juice is affected by strain, culture preparation, state of the cell inoculated, oxygen level, storage temperature, and presence of prebiotics. Microencapsulation of probiotics with inulin has previously been tested for improving viability of the cells in simulated gastric and intestinal juices [5]. Rodriguez et al. [24] reported that microencapsulated Lactobacillus paracasei L26 in alginate with or without double coating resulted in good viability in both orange and peach juices after 50 days of storage at $5{ }^{\circ} \mathrm{C}$. In addition, 
microencapsulated probiotics with chitosan [8] and pectin [25] were able to maintain their viability in fruit juices during refrigeration storage.

\subsection{Sensory Analysis of Pineapple Juice}

Sensory quality of pineapple juice containing microencapsulated $B$. longum with co-encapsulating agents, free cells, and control at $0,15,30$, and 45 days of refrigeration storage are given in Table 4 . Sensory scores of pineapple juice supplemented with free cells and control reduced after refrigeration storage. Overall acceptability of pineapple juice containing co-encapsulated cells was better than that of free cells at day 30 and $45(p<0.05)$. However, the panelist found clear no differences between day 30 and 45 pineapple juice in terms of colour properties $(p>0.05)$. The mean scores for the quality attributes of pineapple juice containing microencapsulated $B$. longum were in the range of 6.34-6.51 (where 6 = like slightly). Total evaluations in term of appearance, color, texture, and taste of the samples containing microencapsulated B. longum were acceptable and did not have any marked off-flavor during the storage period. Moreover, the addition of microcapsules in pineapple juice may increase gritty mouthfeel. However, pineapple juice containing free cells had marked off-flavor due to high concentration of acetic and lactic acids at day 30 and 45. Addition of microencapsulated probiotics in orange juice [26] and bread [27] improved the sensory scores than that of free cells during refrigeration storage.

\subsection{Determination of Organic Acids in Pineapple Juice}

The metabolic activity of microencapsulated B. longum with the extracts and free cells in pineapple juice was estimated by the production of acetic and lactic acids (Figure 1). Concentrations of acetic and lactic acids in pineapple juice were 0.48 and $1.10 \mathrm{~g} \mathrm{~L}^{-1}$, respectively (data not shown). The beads were stored in pineapple juice at $4{ }^{\circ} \mathrm{C}$ for $0,15,30$, and 45 days. Initially, concentrations of the acetic and lactic acids were in the range of $0.42-0.52 \mathrm{~g} \mathrm{~L}^{-1}$ and $1.06-1.19 \mathrm{~g} \mathrm{~L}^{-1}$, respectively. The level of the acids in the juice containing non-encapsulated cells was higher than that of co-encapsulated cells at day 15 , 30 , and 45 ( $p<0.05$ ). The amount of the acids in the pineapple juice containing microencapsulated $B$. longum remained constant after refrigeration storage. The concentration of acetic (Figure 1a) and lactic acids (Figure $1 b$ ) in the juice containing microencapsulated $B$. longum was in the range of $0.41-0.55$ and 1.05-1.20 g L $\mathrm{L}^{-1}$, respectively, during refrigeration storage. Microencapsulation could reduce the problem of over acidification and thus could maintain probiotics during refrigeration storage. In addition, it is possible that local $\mathrm{pH}$ within the microcapsule may protect the probiotics against the external environment [28]. The type of co-encapsulating agents had no influence on concentration of the acids. The $\mathrm{pH}$ of the pineapple juice remained unchanged during 45 days of refrigeration storage due to high buffering capacity of the juice (data not shown). The main carbohydrates in pineapple juice are simple sugars including sucrose, glucose, and fructose. Citric acid is usually present in pineapple juice, followed by lactic acid and a small amount of acetic acid [29]. There is very little information regarding the role of acetic and lactic acids in the survival of probiotics including refrigeration storage. The acids play an important role in anti-inflammatory activity and other intestinal disorders. Probiotics can ferment the sugars into organic acids including acetic and lactic acids. Acids may increase during storage due to enzymes which are still active at $0-5{ }^{\circ} \mathrm{C}$. Acidification could also be due to enzyme releasing from dead bacteria and hydrolyzing sugar in fruit juice [30]. Accordingly, it has previously been reported that microencapsulated 
probiotics had significantly lower acidity than orange and apple juices [31] and fruit food products [26] containing free cells during refrigeration storage.

a

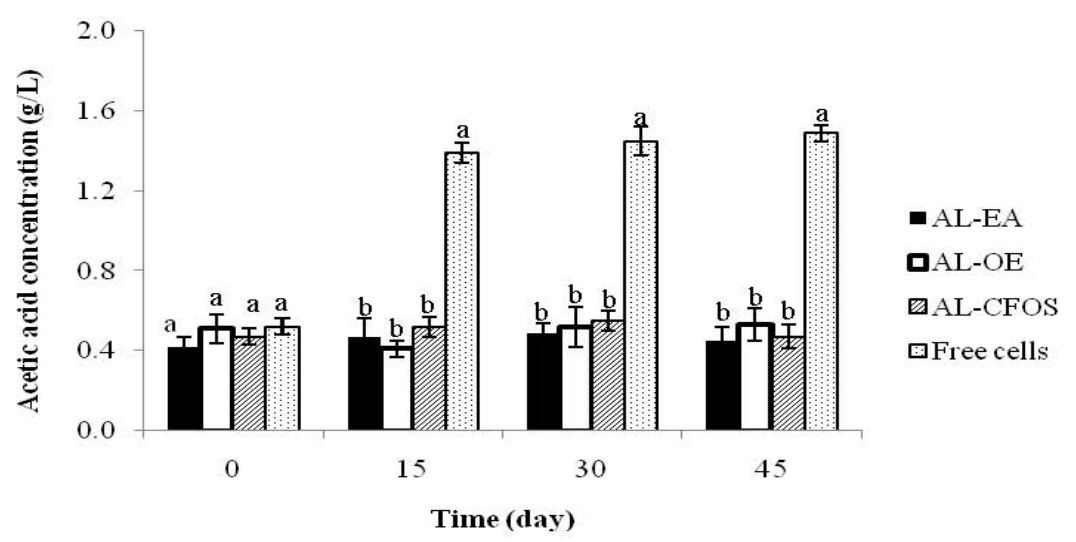

b

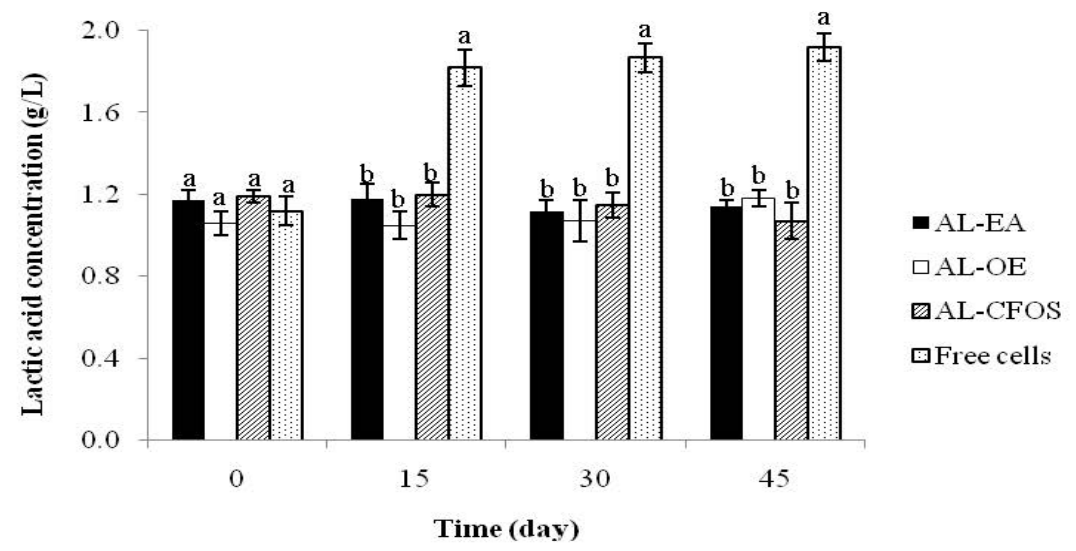

Figure 1. Acetic acid (a) and lactic acid (b) production of pineapple juice containing microencapsulated Bifidobacterium longum with Eleutherine americana during refrigeration storage. Alginate-E.americana extract (AL-EA; black bars), alginate-oligosaccharides extract (AL-OE; white bars), alginate-commercial fructo-oligosaccharides (AL-CFOS; bar with diagonal stripes), and free cells (white bar with black dots). The means \pm standard deviation for at least duplicate are illustrated. Different lowercase letters in co-encapsulating agents are significantly different $(p<0.05)$. 
Table 1. Survival of microencapsulated Bifidobacterium longum with Eleutherine americana in fresh milk tofu during sequential incubation in simulated human gastric and intestinal juices and refrigeration storage.

\begin{tabular}{|c|c|c|c|c|c|}
\hline \multirow{2}{*}{ Microencapsulation } & \multirow{2}{*}{$\begin{array}{c}\text { Time } \\
\text { (Day) }\end{array}$} & \multicolumn{4}{|c|}{ Plate Count $\left(\log _{10} \mathrm{CFU} \mathrm{g}^{-1}\right)$} \\
\hline & & Pre-Gastric Juice & Post-Gastric Juice & Post-Intestinal Juice & Refrigeration Storage \\
\hline Co-encapsulated cells: alginate-E. americana extract & \multirow{4}{*}{0} & $9.46 \pm 0.07 \mathrm{aA}$ & $9.40 \pm 0.10^{\mathrm{aA}}$ & $9.54 \pm 0.19$ aA & $9.44 \pm 0.13^{\mathrm{a}}$ \\
\hline Co-encapsulated cells: alginate-oligosaccharides extract & & $9.38 \pm 0.09 \mathrm{aA}$ & $9.32 \pm 0.11^{\mathrm{aA}}$ & $9.46 \pm 0.04 \mathrm{aA}$ & $9.54 \pm 0.10^{\text {a }}$ \\
\hline Co-encapsulated cells: alginate-commercial fructo-oligosaccharides & & $9.30 \pm 0.10 \mathrm{aA}$ & $9.51 \pm 0.05^{\mathrm{aA}}$ & $9.57 \pm 0.14^{\mathrm{aA}}$ & $9.46 \pm 0.06^{\mathrm{a}}$ \\
\hline Non-encapsulated cells: free cells & & $9.42 \pm 0.07 \mathrm{aA}$ & $9.42 \pm 0.03^{\mathrm{aA}}$ & $9.34 \pm 0.12^{\mathrm{aA}}$ & $9.45 \pm 0.14^{\mathrm{a}}$ \\
\hline Co-encapsulated cells: alginate-E. americana extract & \multirow{4}{*}{2} & $9.36 \pm 0.12 \mathrm{aA}$ & $9.45 \pm 0.11^{\mathrm{aA}}$ & $9.42 \pm 0.06 \mathrm{aA}$ & $9.35 \pm 0.04^{\mathrm{a}}$ \\
\hline Co-encapsulated cells: alginate-oligosaccharides extract & & $9.24 \pm 0.06 \mathrm{aA}$ & $9.32 \pm 0.09 \mathrm{aA}$ & $9.36 \pm 0.03 \mathrm{aA}$ & $9.41 \pm 0.06^{\mathrm{a}}$ \\
\hline Co-encapsulated cells: alginate-commercial fructo-oligosaccharides & & $9.16 \pm 0.12^{\mathrm{aA}}$ & $9.14 \pm 0.04 \mathrm{aA}$ & $9.15 \pm 0.19$ aA & $9.33 \pm 0.14^{\text {a }}$ \\
\hline Non-encapsulated cells: free cells & & $8.47 \pm 0.06^{\mathrm{bA}}$ & $7.45 \pm 0.15^{\mathrm{cB}}$ & $7.30 \pm 0.21^{\mathrm{cB}}$ & $8.30 \pm 0.10^{b}$ \\
\hline Co-encapsulated cells: alginate-E. americana extract & \multirow{4}{*}{4} & $9.25 \pm 0.05^{\mathrm{aA}}$ & $8.37 \pm 0.11^{\mathrm{bB}}$ & $8.28 \pm 0.09 \mathrm{bB}$ & $9.34 \pm 0.07^{\mathrm{a}}$ \\
\hline Co-encapsulated cells: alginate-oligosaccharides extract & & $9.17 \pm 0.12 \mathrm{aA}$ & $8.15 \pm 0.20^{\mathrm{bB}}$ & $8.15 \pm 0.10^{\mathrm{bB}}$ & $9.25 \pm 0.11^{\mathrm{a}}$ \\
\hline Co-encapsulated cells: alginate-commercial fructo-oligosaccharides & & $9.25 \pm 0.16 \mathrm{aA}$ & $8.21 \pm 0.14^{\mathrm{bB}}$ & $8.21 \pm 0.11$ bв & $9.29 \pm 0.11^{\mathrm{a}}$ \\
\hline Non-encapsulated cells: free cells & & $8.35 \pm 0.04$ bA & $6.43 \pm 0.00 \mathrm{~dB}$ & $6.46 \pm 0.07 \mathrm{~dB}$ & $8.12 \pm 0.15^{b}$ \\
\hline Co-encapsulated cells: alginate-E. americana extract & \multirow{4}{*}{6} & $8.38 \pm 0.05^{\mathrm{bA}}$ & $7.36 \pm 0.20 \mathrm{cB}$ & $7.24 \pm 0.16^{\mathrm{cB}}$ & $8.36 \pm 0.06^{b}$ \\
\hline Co-encapsulated cells: alginate-oligosaccharides extract & & $9.24 \pm 0.10^{\mathrm{aA}}$ & $8.52 \pm 0.13^{\mathrm{bB}}$ & $8.23 \pm 0.07^{\mathrm{bB}}$ & $9.24 \pm 0.12^{\mathrm{a}}$ \\
\hline Co-encapsulated cells: alginate-commercial fructo-oligosaccharides & & $8.45 \pm 0.11^{\mathrm{bA}}$ & $7.19 \pm 0.15^{\mathrm{cB}}$ & $7.26 \pm 0.12^{\mathrm{cB}}$ & $8.25 \pm 0.11^{b}$ \\
\hline Non-encapsulated cells: free cells & & $6.42 \pm 0.08^{\mathrm{cA}}$ & $5.34 \pm 0.06^{\mathrm{eB}}$ & $3.56 \pm 0.16^{\mathrm{eC}}$ & $6.24 \pm 0.06^{\mathrm{c}}$ \\
\hline
\end{tabular}

Values are means \pm standard deviation from duplicate determinations; Different superscript uppercase letters (A,B) in the same row are significantly different among gastrointestinal conditions $(p<0.05)$; Different superscript lowercase letters (a-e) in the same column are significantly different among co-encapsulating agents $(p<0.05)$. 
Table 2. Sensory scores of fresh milk tofu supplemented with microencapsulated Bifidobacterium longum with Eleutherine americana during refrigeration storage.

\begin{tabular}{|c|c|c|c|c|c|c|}
\hline \multirow{2}{*}{ Microencapsulation } & \multirow{2}{*}{$\begin{array}{c}\text { Time } \\
\text { (Day) }\end{array}$} & \multicolumn{5}{|c|}{ Attributes } \\
\hline & & Appearance & Colour & Texture & Taste & Overall Acceptability \\
\hline Co-encapsulated cells: alginate-E. americana extract & & $7.15 \pm 0.09^{\mathrm{a}}$ & $7.40 \pm 0.16^{\mathrm{a}}$ & $7.47 \pm 0.12^{a}$ & $7.45 \pm 0.10^{a}$ & $7.42 \pm 0.06^{\mathrm{a}}$ \\
\hline Co-encapsulated cells: alginate-oligosaccharides extract & & $7.10 \pm 0.12^{\mathrm{a}}$ & $7.35 \pm 0.11^{\text {a }}$ & $7.55 \pm 0.10^{\text {a }}$ & $7.49 \pm 0.24^{\mathrm{a}}$ & $7.34 \pm 0.13^{\mathrm{a}}$ \\
\hline Co-encapsulated cells: alginate-commercial fructo-oligosaccharides & 0 & $7.27 \pm 0.07^{\mathrm{a}}$ & $7.29 \pm 0.08^{\mathrm{a}}$ & $7.30 \pm 0.09$ a & $7.53 \pm 0.14^{\mathrm{a}}$ & $7.56 \pm 0.09^{\mathrm{a}}$ \\
\hline Non-encapsulated cells: free cells & & $6.95 \pm 0.07^{\mathrm{a}}$ & $7.48 \pm 0.05^{\mathrm{a}}$ & $7.37 \pm 0.18^{a}$ & $7.40 \pm 0.15^{\mathrm{a}}$ & $7.45 \pm 0.10^{\mathrm{a}}$ \\
\hline Control & & $7.31 \pm 0.07^{\mathrm{a}}$ & $7.25 \pm 0.04^{\mathrm{a}}$ & $7.16 \pm 0.11^{\mathrm{a}}$ & $7.33 \pm 0.14^{\mathrm{a}}$ & $7.48 \pm 0.10^{\mathrm{a}}$ \\
\hline Co-encapsulated cells: alginate-E. americana extract & & $7.47 \pm 0.16^{\mathrm{a}}$ & $7.21 \pm 0.20^{\mathrm{a}}$ & $7.45 \pm 0.17^{\mathrm{a}}$ & $7.51 \pm 0.13^{\mathrm{a}}$ & $7.42 \pm 0.14^{\mathrm{a}}$ \\
\hline Co-encapsulated cells: alginate-oligosaccharides extract & & $7.27 \pm 0.05^{\mathrm{a}}$ & $6.90 \pm 0.08^{\text {a }}$ & $7.39 \pm 0.03^{\mathrm{a}}$ & $7.39 \pm 0.16^{\mathrm{a}}$ & $7.51 \pm 0.13^{\mathrm{a}}$ \\
\hline Co-encapsulated cells: alginate-commercial fructo-oligosaccharides & 2 & $7.13 \pm 0.18^{\mathrm{a}}$ & $7.14 \pm 0.10^{\mathrm{a}}$ & $7.26 \pm 0.19^{\text {a }}$ & $7.35 \pm 0.10^{\text {a }}$ & $7.34 \pm 0.05^{\mathrm{a}}$ \\
\hline Non-encapsulated cells: free cells & & $7.52 \pm 0.19^{a}$ & $7.12 \pm 0.14^{\mathrm{a}}$ & $7.41 \pm 0.21^{\mathrm{a}}$ & $7.49 \pm 0.08^{a}$ & $7.45 \pm 0.18^{\mathrm{a}}$ \\
\hline Control & & $7.37 \pm 0.09^{\mathrm{a}}$ & $7.34 \pm 0.12^{\mathrm{a}}$ & $7.26 \pm 0.07^{\mathrm{a}}$ & $7.41 \pm 0.11^{\mathrm{a}}$ & $7.40 \pm 0.06^{\mathrm{a}}$ \\
\hline Co-encapsulated cells: alginate-E. americana extract & & $7.27 \pm 0.09^{\mathrm{a}}$ & $7.35 \pm 0.14^{\mathrm{a}}$ & $7.18 \pm 0.14^{\mathrm{a}}$ & $7.27 \pm 0.15^{\mathrm{a}}$ & $7.26 \pm 0.13^{\mathrm{a}}$ \\
\hline Co-encapsulated cells: alginate-oligosaccharides extract & & $7.24 \pm 0.05^{\mathrm{a}}$ & $7.17 \pm 0.15^{\mathrm{a}}$ & $7.20 \pm 0.20^{\mathrm{a}}$ & $7.19 \pm 0.10^{\mathrm{a}}$ & $7.34 \pm 0.04^{\mathrm{a}}$ \\
\hline Co-encapsulated cells: alginate-commercial fructo-oligosaccharides & 4 & $7.36 \pm 0.10^{\text {a }}$ & $7.32 \pm 0.12^{\text {a }}$ & $7.15 \pm 0.11^{\mathrm{a}}$ & $7.32 \pm 0.14^{\mathrm{a}}$ & $7.42 \pm 0.14^{\mathrm{a}}$ \\
\hline Non-encapsulated cells: free cells & & $6.22 \pm 0.14^{b}$ & $7.20 \pm 0.10^{\mathrm{a}}$ & $6.23 \pm 0.16^{b}$ & $6.31 \pm 0.09^{b}$ & $6.35 \pm 0.16^{b}$ \\
\hline Control & & $6.32 \pm 0.10^{b}$ & $7.25 \pm 0.12^{\mathrm{a}}$ & $6.34 \pm 0.06^{b}$ & $6.35 \pm 0.08^{b}$ & $6.37 \pm 0.12^{b}$ \\
\hline Co-encapsulated cells: alginate-E. americana extract & & $7.31 \pm 0.06^{\mathrm{a}}$ & $7.39 \pm 0.16^{a}$ & $7.18 \pm 0.06^{\mathrm{a}}$ & $7.35 \pm 0.20^{\mathrm{a}}$ & $7.52 \pm 0.12^{\mathrm{a}}$ \\
\hline Co-encapsulated cells: alginate-oligosaccharides extract & & $7.16 \pm 0.17^{\mathrm{a}}$ & $7.28 \pm 0.23^{a}$ & $7.23 \pm 0.13^{\mathrm{a}}$ & $7.19 \pm 0.15^{\mathrm{a}}$ & $7.45 \pm 0.09^{\mathrm{a}}$ \\
\hline Co-encapsulated cells: alginate-commercial fructo-oligosaccharides & 6 & $7.22 \pm 0.09^{a}$ & $7.16 \pm 0.14^{\mathrm{a}}$ & $7.25 \pm 0.11^{\mathrm{a}}$ & $7.24 \pm 0.11^{\mathrm{a}}$ & $7.37 \pm 0.10^{\mathrm{a}}$ \\
\hline Non-encapsulated cells: free cells & & $6.13 \pm 0.14^{b}$ & $7.23 \pm 0.09$ a & $6.14 \pm 0.00^{b}$ & $6.10 \pm 0.14^{b}$ & $6.41 \pm 0.13^{b}$ \\
\hline Control & & $6.20 \pm 0.12^{b}$ & $7.27 \pm 0.08^{\mathrm{a}}$ & $6.27 \pm 0.10^{b}$ & $6.22 \pm 0.08^{b}$ & $6.40 \pm 0.11^{b}$ \\
\hline
\end{tabular}

Values are means \pm standard deviation from duplicate determinations; Different superscript lowercase letters (a,b) in the same column are significantly different among co-encapsulating agents $(p<0.05)$. 
Table 3. Survival of microencapsulated Bifidobacterium longum with Eleutherine americana in pineapple juice during sequential incubation in simulated human gastric and intestinal juices and refrigeration storage.

\begin{tabular}{|c|c|c|c|c|c|}
\hline \multirow{2}{*}{ Microencapsulation } & \multirow{2}{*}{$\begin{array}{c}\text { Time } \\
\text { (Day) }\end{array}$} & \multicolumn{4}{|c|}{ Plate Count $\left(\log _{10} \mathrm{CFU} / \mathrm{g}\right)$} \\
\hline & & Pre-Gastric Juice & Post-Gastric Juice & Post-Intestinal Juice & Refrigeration Storage \\
\hline Co-encapsulated cells: alginate-E. americana extract & \multirow{4}{*}{0} & $9.55 \pm 0.15^{\mathrm{aA}}$ & $9.45 \pm 0.12 \mathrm{aA}$ & $9.35 \pm 0.08$ aA & $9.38 \pm 0.14^{\mathrm{a}}$ \\
\hline Co-encapsulated cells: alginate-oligosaccharides extract & & $9.42 \pm 0.10^{\mathrm{aA}}$ & $9.32 \pm 0.16$ aA & $9.46 \pm 0.17^{\mathrm{aA}}$ & $9.50 \pm 0.12^{\mathrm{a}}$ \\
\hline Co-encapsulated cells: alginate-commercial fructo-oligosaccharides & & $9.30 \pm 0.07 \mathrm{aA}$ & $9.51 \pm 0.09 \mathrm{aA}$ & $9.26 \pm 0.26 \mathrm{aA}$ & $9.47 \pm 0.14^{\text {a }}$ \\
\hline Non-encapsulated cells: free cells & & $9.34 \pm 0.04^{\mathrm{aA}}$ & $9.42 \pm 0.08 \mathrm{aA}$ & $9.37 \pm 0.09 \mathrm{aA}$ & $9.39 \pm 0.16^{\mathrm{a}}$ \\
\hline Co-encapsulated cells: alginate-E. americana extract & \multirow{4}{*}{15} & $8.20 \pm 0.12^{\mathrm{bA}}$ & $7.41 \pm 0.15^{\mathrm{cB}}$ & $7.30 \pm 0.08^{\mathrm{cB}}$ & $8.35 \pm 0.12^{b}$ \\
\hline Co-encapsulated cells: alginate-oligosaccharides extract & & $9.15 \pm 0.07 \mathrm{aA}$ & $8.34 \pm 0.04$ bB & $8.39 \pm 0.13^{\mathrm{bB}}$ & $9.41 \pm 0.05^{\mathrm{a}}$ \\
\hline Co-encapsulated cells: alginate-commercial fructo-oligosaccharides & & $8.12 \pm 0.13 \mathrm{bA}$ & $7.12 \pm 0.06^{\mathrm{cB}}$ & $7.42 \pm 0.11^{\mathrm{cB}}$ & $8.26 \pm 0.16^{\mathrm{b}}$ \\
\hline Non-encapsulated cells: free cells & & $3.59 \pm 0.04 \mathrm{dA}$ & $2.65 \pm 0.11^{\mathrm{eB}}$ & $2.32 \pm 0.04 \mathrm{eB}^{\mathrm{eB}}$ & $3.42 \pm 0.10^{\mathrm{d}}$ \\
\hline Co-encapsulated cells: alginate-E. americana extract & \multirow{4}{*}{30} & $8.25 \pm 0.06^{\mathrm{bA}}$ & $7.35 \pm 0.14^{\mathrm{cB}}$ & $7.25 \pm 0.06^{\mathrm{cB}}$ & $8.43 \pm 0.12^{b}$ \\
\hline Co-encapsulated cells: alginate-oligosaccharides extract & & $9.14 \pm 0.10^{\mathrm{aA}}$ & $8.24 \pm 0.13^{\mathrm{bB}}$ & $8.24 \pm 0.07$ bB & $9.34 \pm 0.10^{\mathrm{a}}$ \\
\hline Co-encapsulated cells: alginate-commercial fructo-oligosaccharides & & $8.21 \pm 0.09 \mathrm{bA}$ & $7.18 \pm 0.04$ cB & $7.15 \pm 0.06$ cB & $8.26 \pm 0.08^{b}$ \\
\hline Non-encapsulated cells: free cells & & $0.00 \pm 0.00 \mathrm{eA}$ & $0.00 \pm 0.00 \mathrm{fA}$ & $0.00 \pm 0.00 \mathrm{fA}$ & $0.00 \pm 0.00^{\mathrm{e}}$ \\
\hline Co-encapsulated cells: alginate-E. americana extract & \multirow{4}{*}{45} & $7.21 \pm 0.07 \mathrm{cA}$ & $6.37 \pm 0.11 \mathrm{~dB}$ & $6.34 \pm 0.06 \mathrm{~dB}$ & $7.20 \pm 0.11^{\mathrm{c}}$ \\
\hline Co-encapsulated cells: alginate-oligosaccharides extract & & $8.23 \pm 0.13^{\mathrm{bA}}$ & $7.24 \pm 0.05^{\mathrm{cB}}$ & $7.25 \pm 0.09 \mathrm{cB}$ & $8.28 \pm 0.09^{b}$ \\
\hline Co-encapsulated cells: alginate-commercial fructo-oligosaccharides & & $7.32 \pm 0.10^{\mathrm{cA}}$ & $6.15 \pm 0.11 \mathrm{~dB}$ & $6.23 \pm 0.10^{\mathrm{dB}}$ & $7.34 \pm 0.15^{c}$ \\
\hline Non-encapsulated cells: free cells & & $0.00 \pm 0.00 \mathrm{eA}$ & $0.00 \pm 0.00^{\mathrm{fA}}$ & $0.00 \pm 0.00^{\mathrm{fA}}$ & $0.00 \pm 0.00^{\mathrm{e}}$ \\
\hline
\end{tabular}

Values are means \pm standard deviation from duplicate determinations; Different superscript uppercase letters (A,B) in the same row are significantly different among gastrointestinal conditions $(p<0.05)$; Different superscript lowercase letters $(\mathrm{a}-\mathrm{f})$ in the same column are significantly different among co-encapsulating agents $(p<0.05)$. 
Table 4. Sensory scores of pineapple juice supplemented with microencapsulated Bifidobacterium longum with Eleutherine americana during refrigeration storage.

\begin{tabular}{|c|c|c|c|c|c|c|}
\hline \multirow{2}{*}{ Microencapsulation } & \multirow{2}{*}{$\begin{array}{c}\text { Time } \\
\text { (Day) }\end{array}$} & \multicolumn{5}{|c|}{ Attributes } \\
\hline & & Appearance & Colour & Texture & Taste & Overall Acceptability \\
\hline Co-encapsulated cells: alginate-E. americana extract & & $6.53 \pm 0.17^{\text {a }}$ & $6.37 \pm 0.22^{\text {a }}$ & $6.42 \pm 0.17^{\mathrm{a}}$ & $6.37 \pm 0.13^{\text {a }}$ & $6.46 \pm 0.11^{\mathrm{a}}$ \\
\hline Co-encapsulated cells: alginate-oligosaccharides extract & & $6.44 \pm 0.11^{\text {a }}$ & $6.32 \pm 0.12^{\text {a }}$ & $6.52 \pm 0.13^{a}$ & $6.12 \pm 0.11^{\mathrm{a}}$ & $6.34 \pm 0.15^{\mathrm{a}}$ \\
\hline Co-encapsulated cells: alginate-commercial fructo-oligosaccharides & 0 & $6.35 \pm 0.05^{\text {a }}$ & $6.51 \pm 0.09^{a}$ & $6.33 \pm 0.16^{\mathrm{a}}$ & $6.06 \pm 0.04$ a & $6.51 \pm 0.12^{\text {a }}$ \\
\hline Non-encapsulated cells: free cells & & $6.42 \pm 0.09$ a & $6.44 \pm 0.07^{\mathrm{a}}$ & $6.46 \pm 0.15^{\mathrm{a}}$ & $6.17 \pm 0.15^{\mathrm{a}}$ & $6.45 \pm 0.20^{\text {a }}$ \\
\hline Control & & $6.37 \pm 0.09^{\text {a }}$ & $6.35 \pm 0.12^{\text {a }}$ & $6.34 \pm 0.10^{\text {a }}$ & $6.30 \pm 0.11^{\text {a }}$ & $6.41 \pm 0.15^{\text {a }}$ \\
\hline Co-encapsulated cells: alginate-E. americana extract & & $6.46 \pm 0.17^{\mathrm{a}}$ & $6.36 \pm 0.22^{a}$ & $6.40 \pm 0.12^{a}$ & $6.37 \pm 0.13^{a}$ & $6.47 \pm 0.14^{\mathrm{a}}$ \\
\hline Co-encapsulated cells: alginate-oligosaccharides extract & & $6.41 \pm 0.06^{\text {a }}$ & $6.41 \pm 0.09^{\text {a }}$ & $6.39 \pm 0.10^{\mathrm{a}}$ & $6.41 \pm 0.09$ a & $6.45 \pm 0.11^{\mathrm{a}}$ \\
\hline Co-encapsulated cells: alginate-commercial fructo-oligosaccharides & 15 & $6.36 \pm 0.23^{a}$ & $6.35 \pm 0.11^{\text {a }}$ & $6.29 \pm 0.15^{\mathrm{a}}$ & $6.35 \pm 0.14^{\mathrm{a}}$ & $6.37 \pm 0.09$ a \\
\hline Non-encapsulated cells: free cells & & $6.34 \pm 0.244^{a}$ & $6.45 \pm 0.21^{\mathrm{a}}$ & $6.35 \pm 0.14^{\mathrm{a}}$ & $6.38 \pm 0.13^{a}$ & $6.49 \pm 0.10^{a}$ \\
\hline Control & & $6.45 \pm 0.08^{a}$ & $6.37 \pm 0.10^{a}$ & $6.30 \pm 0.08^{a}$ & $6.35 \pm 0.14^{\mathrm{a}}$ & $6.40 \pm 0.12^{\mathrm{a}}$ \\
\hline Co-encapsulated cells: alginate-E. americana extract & & $6.61 \pm 0.06^{\text {a }}$ & $6.34 \pm 0.12^{\text {a }}$ & $6.40 \pm 0.09^{\mathrm{a}}$ & $6.25 \pm 0.13^{\text {a }}$ & $6.46 \pm 0.14^{\mathrm{a}}$ \\
\hline Co-encapsulated cells: alginate-oligosaccharides extract & & $6.39 \pm 0.15^{a}$ & $6.35 \pm 0.15^{\text {a }}$ & $6.37 \pm 0.15^{\text {a }}$ & $6.18 \pm 0.15^{\mathrm{a}}$ & $6.38 \pm 0.12^{\text {a }}$ \\
\hline Co-encapsulated cells: alginate-commercial fructo-oligosaccharides & 30 & $6.42 \pm 0.14^{\mathrm{a}}$ & $6.38 \pm 0.14^{\mathrm{a}}$ & $6.25 \pm 0.11^{\mathrm{a}}$ & $6.26 \pm 0.12^{\mathrm{a}}$ & $6.42 \pm 0.20^{\mathrm{a}}$ \\
\hline Non-encapsulated cells: free cells & & $5.52 \pm 0.13^{b}$ & $6.40 \pm 0.07^{\mathrm{a}}$ & $5.46 \pm 0.09^{b}$ & $5.31 \pm 0.12^{b}$ & $5.51 \pm 0.13^{b}$ \\
\hline Control & & $5.40 \pm 0.09^{b}$ & $6.34 \pm 0.10^{a}$ & $5.37 \pm 0.08^{b}$ & $6.34 \pm 0.12^{\mathrm{a}}$ & $5.54 \pm 0.10^{b}$ \\
\hline Co-encapsulated cells: alginate-E. americana extract & & $6.29 \pm 0.06^{\text {a }}$ & $6.24 \pm 0.15^{\text {a }}$ & $6.34 \pm 0.10^{\text {a }}$ & $6.22 \pm 0.10^{\text {a }}$ & $6.40 \pm 0.13^{\mathrm{a}}$ \\
\hline Co-encapsulated cells: alginate-oligosaccharides extract & & $6.31 \pm 0.15^{\text {a }}$ & $6.17 \pm 0.20^{\text {a }}$ & $6.41 \pm 0.12^{\mathrm{a}}$ & $6.18 \pm 0.08^{\text {a }}$ & $6.36 \pm 0.11^{\text {a }}$ \\
\hline Co-encapsulated cells: alginate-commercial fructo-oligosaccharides & 45 & $6.25 \pm 0.14^{\mathrm{a}}$ & $6.19 \pm 0.14^{\mathrm{a}}$ & $6.39 \pm 0.13^{a}$ & $6.26 \pm 0.11^{\text {a }}$ & $6.42 \pm 0.09$ a \\
\hline Non-encapsulated cells: free cells & & $5.35 \pm 0.00^{b}$ & $6.12 \pm 0.00^{\mathrm{a}}$ & $5.34 \pm 0.00^{b}$ & $5.31 \pm 0.16^{b}$ & $5.37 \pm 0.15^{b}$ \\
\hline Control & & $5.32 \pm 0.12^{b}$ & $6.37 \pm 0.10^{\mathrm{a}}$ & $5.30 \pm 0.09^{b}$ & $6.32 \pm 0.09^{a}$ & $5.57 \pm 0.15^{b}$ \\
\hline
\end{tabular}

Values are means \pm standard deviation from duplicate determinations; Different superscript lowercase letters (a,b) in the same column are significantly different among co-encapsulating agents $(p<0.05)$. 


\section{Conclusions}

Microencapsulated Bifidobacterium longum with Eleutherine americana extract and its oligosaccharides extract in fresh milk tofu and pineapple juice showed better survival than free cells after sequential incubation in simulated gastric and intestinal juices and refrigeration storage. Microencapsulated cells appeared to be effective in improving the sensory quality of the food products. Addition of microencapsulated cells in the pineapple juice caused a slowing of post-acidification during refrigeration storage. Further studies are warranted in animal models before potential application for consumers.

\section{Acknowledgments}

This research was supported by grants under the program Strategic Scholarships for Frontier Research Network for the Program Thai Doctoral degree and TRF Senior Research Scholarship, Fiscal Year 2015-2018.

\section{Author Contributions}

Atchara N Phoem designed the experiments, performed the experiments, analysed the data, and wrote the manuscript. Suphichaya Chanthachum co-supervised microencapsulation part and Supayang P Voravuthikunchai supervised the project and edited the manuscript.

\section{Conflicts of Interest}

The authors declare no conflict of interest

\section{References}

1. Muthukumarasamy, P.; Holley, R.A. Microbiological and sensory quality of dry fermented sausages containing alginate-microencapsulated Lactobacillus reuteri. Int. J. Food Microbiol. 2006, 111, 164-169.

2. Shah, N.P. Functional cultures and health benefits. Int. Dairy J. 2007, 17, 1262-1277.

3. Granato, D.; Branco, G.F.; Nazzaro, F.; Cruz, A.G.; Faria, J.A. Functional foods and nondairy probiotic food development: Trends, concepts, and products. Compr. Rev. Food Sci. Food Saf. 2010, 9, 292-302.

4. Gobbetti, M.; Cagno, R.D.; de Angelis, M. Functional microorganisms for functional food quality. Crit. Rev. Food Sci. Nutr. 2010, 50, 716-727.

5. Nazzaro, F.; Fratianni, F.; Coppola, R.; Sada, A.; Orlando, P. Fermentative ability of alginate-prebiotic encapsulated Lactobacillus acidophilus and survival under simulated gastrointestinal conditions. J. Funct. Food 2009, 1, 319-323.

6. Li, X.Y.; Chen, X.G.; Sun, Z.W.; Park, H.J.; Cha, D.S. Preparation of alginate/chitosan/ carboxymethyl chitosan complex microcapsules and application in Lactobacillus casei ATCC 393. Carbohydr. Polym. 2011, 83, 1479-1485. 
7. Mirzaei, H.; Pourjafar, H.; Homayouni, A. Effect of calcium alginate and resistant starch microencapsulation on the survival rate of Lactobacillus acidophilus La5 and sensory properties in Iranian white brined cheese. Food Chem. 2012, 132, 1966-1970.

8. Nualkaekul, S.; Lenton, D.; Cook, M.T.; Khutoryanskiy, V.V.; Charalampopoulos, D. Chitosan coated alginate beads for the survival of microencapsulated Lactobacillus plantarum in pomegranate juice. Carbohydr. Polym. 2012, 90, 1281-1287.

9. Ifesan, B.; Hamtasin, C.; Mahabusarakam, W.; Voravuthikunchai, S. Inhibitory effect of Eleutherine americana Merr. extract on Staphylococcus aureus Isolated from food. J. Food Sci. 2009, 74, M31-M36.

10. Ifesan, B.O.T.; Siripongvutikorn, S.; Voravuthikunchai, S.P. Application of Eleutherine americana crude extract in homemade salad dressing. J. Food Protect. 2009, 72, 650-655.

11. Phoem, A.N.; Voravuthikunchai, S.P. Eleutherine americana as a growth promotor for infant intestinal microbiota. Anaerobe 2013, 20, 14-19.

12. Phoem, A.N.; Voravuthikunchai, S.P. Growth stimulation/inhibition effect of medicinal plants on human intestinal microbiota. Food Sci. Biotechnol. 2012, 21, 739-745.

13. Krasaekoopt, W.; Bhandari, B.; Deeth, H. The influence of coating materials on some properties of alginate beads and survivability of microencapsulated probiotic bacteria. Int. Dairy J. 2004, 14, 737-743.

14. Sandoval-Castilla, O.; Lobato-Calleros, C.; Garcia-Galindo, H.S.; Alvarez-Ramirez, J.; Vernon-Carter, E.J. Textural properties of alginate-pectin beads and survivability of entrapped $L b$. casei in simulated gastrointestinal conditions and in yoghurt. Food Res. Int. 2010, 43, 111-117.

15. Brinques, G.B.; Ayub, M.A.Z. Effect of microencapsulation on survival of Lactobacillus plantarum in simulated gastrointestinal conditions, refrigeration, and yogurt. J. Food Eng. 2011, 103, 123-128.

16. Bergara-Almeida, S.; Aparecida, M.; Da Silva, A. Hedonic scale with reference: Performance in obtaining predictive models. Food Qual. Prefer. 2002, 13, 57-64.

17. Holdeman, L.V., Moore, W.E.C. Anaerobe Laboratory Manual; Virginia Polytechnic Institute and State University: Blacksburg, VA, USA, 1977.

18. Mokarram, R.R.; Mortazavi, S.A.; Najafi, M.B.H.; Shahidi, F. The influence of multi stage alginate coating on survivability of potential probiotic bacteria in simulated gastric and intestinal juice. Food Res. Int. 2009, 42, 1040-1045.

19. Amine, K.M.C., C.P.; Raymond, Y.; st-Gelais, D.; Britten, M.; Fustier, P.; Salmieri, S.; Lacroix, M. Survival of microencapsulated Bifidobacterium longum in Cheddar cheese during production and storage. Food Control. 2014, 37, 193-199.

20. Homayouni, A.; Azizi, A.; Ehsani, M.R.; Yarmand, M.S.; Razavi, S.H. Effect of microencapsulation and resistant starch on the probiotic survival and sensory properties of synbiotic ice cream. Food Chem. 2008, 111, 50-55.

21. Pinto, S.S.; Fritzen-Freire, C.B.; Munoz, I.B.; Barreto, P.L.M.; Prudencio, E.S.; Amboni, R.D. Effects of the addition of microencapsulated Bifidobacterium BB-12 on the properties of frozen yogurt. J. Food Eng. 2012, 111, 563-569.

22. Kailasapathy, K. Survival of free and encapsulated probiotic bacteria and their effect on the sensory properties of yoghurt. LWT-Food Sci. Technol. 2006, 39, 1221-1227. 
23. Shabala, L.; Mcmeekin, T.; Budde, B.B.; Siegumfeldt, H. Listeria innocua and Lactobacillus delbrueckii subsp. bulgaricus employ different strategies to cope with acid stress. Int. J. Food Microbiol. 2006, 110, 1-7.

24. Rodriquez, D.; Sousa, S.; Gomes, A.M.; Pintado, M.M.; Silva, J.P.; Costa, P.; Amaral, M.H.; Rocha-Santos, T.; Freitas, A.C. Storage stability of Lactobacillus paracasei as free cells or encapsulated in alginate-based microcapsules in low $\mathrm{pH}$ fruit juices. Food Bioprocess Technol. 2012, 5, 2748-2757.

25. Nualkaekul, S.C.; Cook, M.T.; Khutoryyanskiy, V.V.; Charalampopulos, D. Influence of encapsulation and coating materials on the survival of Lactobacillus plantarum and Bifidobacterium longum in fruit juices. Food Res. Int. 2013, 53, 304-311.

26. Sohail, A.; Turner, M.S.; Prabawati, E.K.; Coombes, A.G.; Bhandari, B. Evaluation of Lactobacillus rhamnosus GG and Lactobacillus acidophilus NCFM encapsulated using a novel impinging aerosol method in fruit food products. Int. J. Food Microbiol. 2012, 157, 162-166.

27. Altamirano-Fortoul, R.; Moreno-Terrazas, R.; Quezada-Gallo, A.; Rosell, C.M. Viability of some probiotic coatings in bread and its effect on the crust mechanical properties. Food Hydrocoll. 2012, 29, 166-174.

28. Ying, D.; Schwander, S.; Weerakkody, R.; Sanguansri, L.; Gantenbein-Demarchi, C.; Augustin, M.A. Microencapsulated Lactobacillus rhamnosus GG in whey protein and resistant starch matrices: Probiotic survival in fruit juice. J. Funct. Food. 2013, 5, 98-105.

29. Di Cagno, R.; Cardinali, G.; Minervini, G.; Antonielli, L.; Rizzello, C.G.; Ricciuti, P.; Gobbetti, M. Taxonomic structure of the yeasts and lactic acid bacteria microbiota of pineapple (Ananas comosus L. Merr.) and use of autochthonous starters for minimally processing. Food Microbiol. 2010, 27, 381-389.

30. Nualkaekul, S.; Charalampopoulos, D. Survival of Lactobacillus plantarum in model solutions and fruit juices. Int. J. Food Microbiol. 2011, 146, 111-117.

31. Ding, W.; Shah, N.P. Survival of free and microencapsulated probiotic bacteria in orange and apple juices. Int. Food Res. J. 2008, 15, 219-232.

(C) 2015 by the authors; licensee MDPI, Basel, Switzerland. This article is an open access article distributed under the terms and conditions of the Creative Commons Attribution license (http://creativecommons.org/licenses/by/4.0/). 